\title{
Deconvolution Analysis of Spontaneous Nocturnal Growth Hormone Secretion in Prepubertal Children with Preterminal Chronic Renal Failure and with End-Stage Renal Disease
}

\author{
BURKHARD TÖNSHOFF, JOHANNES D. VELDHUIS, UDO HEINRICH, AND OTTO MEHLS \\ Division of Pediatric Nephrology [B.T., O.M.] and Department of Pediatric Endocrinology, \\ University Children's Hospital, Heidelberg, Germany [U.H.], and Division of Endocrinology and \\ Metabolism, Department of Internal Medicine, National Science Foundation Science Center in \\ Biological Timing, University of Virginia Health Sciences Center, Charlottesville, Virginia 22908 [J.D.V.]
}

\begin{abstract}
ABST
We sought to determine whether elevated circulating growth
hormone $(\mathrm{GH})$ concentrations in uremic prepubertal children are due to an increase in GH secretory activity by the pituitary gland or a decrease in the metabolic clearance of $\mathrm{GH}$ consequent to reduced GFR. Deconvolution analysis was applied to the nighttime plasma $\mathrm{GH}$ profiles of 1) 11 children with preterminal chronic renal failure, 2) 12 children with end-stage renal disease (ESRD), and 3) a control group of matched children with idiopathic short stature $(n=12)$. Mean $( \pm$ SEM) half-life of endogenous $\mathrm{GH}$ in children with ESRD $(27.5 \pm 2.7 \mathrm{~min})$ and preterminal chronic renal failure $(23.1 \pm 2.1 \mathrm{~min})$ was significantly higher than in controls $(14.8 \pm 1.6 \mathrm{~min} ; p<0.001)$. GH half-life correlated inversely with GFR $(r=-0.65, p<0.001)$. The number of GH secretory bursts/10 $\mathrm{h}$ in ESRD $(8.1 \pm 0.4)$ was amplified compared with preterminal chronic renal failure $(6.4 \pm 0.5)$ and with controls $(5.9 \pm 0.4 ; p<0.005)$. GH production rate varied over a broad range in the three groups: It was highest in ESRD (202 $\pm 56.6 \mathrm{mg} / \mathrm{L} / 10 \mathrm{~h}$; range $36-683)$, mainly as a result of an increased number of GH secretory bursts, and not statistically different in preterminal chronic renal failure
\end{abstract}

$(66.2 \pm 11.4 \mathrm{mg} / \mathrm{L} / 10 \mathrm{~h}$; range $25-168)$ and in controls (129 \pm $27.7 \mathrm{mg} / \mathrm{L} / 10 \mathrm{~h}$; range 39-392). Increased $\mathrm{GH}$ half-life, in concert with an increased $\mathrm{GH}$ production in some individuals with ESRD, leads to a 2.5-fold increase in the mean plasma $\mathrm{GH}$ concentration in ESRD compared with the two other groups ( $p<$ 0.005 ). However, total immunoreactive plasma IGF-I levels were indistinguishable between groups. This disruption of the normal relationship between circulating GH and total plasma IGF-I levels in ESRD suggests a relative insensitivity to the action of $\mathrm{GH}$ in uremia, at least in those target organs (e.g. liver) that contribute predominantly to circulating IGF-I levels. (Pediatr Res 37: 86-93, 1995)

BMI, body mass index

\section{Abbreviations}

CRF, chronic renal failure

ESRD, end-stage renal disease

GH, growth hormone

GHRH, growth hormone-releasing hormone ISS, idiopathic short stature
Inasmuch as impaired linear growth is an inevitable problem in children with CRF, numerous studies have investigated possible alterations of the GH/IGF axis in uremia (1). Fasting plasma $\mathrm{GH}$ concentrations are elevated in children and adults with CRF, depending on the degree of renal failure $(2,3)$. However, these studies are difficult to interpret, because dynamic facets of the $\mathrm{GH}$ axis, such as specific physiologic

Received April 4, 1994; accepted July 27, 1994.

Correspondence: Dr. Burkhard Tönshoff, Division of Pediatric Nephrology, Department of Pediatrics, School of Medicine, State University of New York at Stony Brook, Stony Brook, NY 11794-8111.

B.T. is supported by a Feodor Lynen grant from the Alexander von Humboldt-Stiftung J.D.V. is recipient of National Institutes of Health Research Career Development Award IK04HD00634 from the National Institute of Child Health and Human Development, National Institutes of Health, Bethesda, M.D., and a Baxter Health Care Corp. grant-in-aid (Round Lake, IL). regulation of the frequency and amplitude of pulsatile $\mathrm{GH}$ secretion, cannot be quantitated accurately in single blood determinations. Measurements of pulsatile plasma GH concentrations have been performed in prepubertal (4) and pubertal (5) children with CRF. Unfortunately, both studies lacked suitable control groups and did not provide insights into neurosecretory events and concurrent hormone clearance that together underlie the plasma GH pulse patterns. Such information is important particularly in patients with CRF, because the kidney is believed to account for a substantial fraction of the total plasma turnover of $\mathrm{GH}$ in humans (25-53\%) (6) and in rats $(67 \%)$ (7). Thus, in children with CRF, the question remains unresolved whether increased plasma GH concentrations are primarily due to increased $\mathrm{GH}$ secretion or decreased GH elimination by the kidney. 
The application to clinical studies of a new mathematical technique, deconvolution analysis, can permit the estimation of endogenous hormone secretory rates and clearance kinetics from pulsatile plasma hormone concentration profiles without prior knowledge of the metabolic clearance rate of the hormone $(8-11)$. This is achieved by mathematical removal of the impact of hormone clearance kinetics on the pulsatile hormone profile to uncover specific pituitary secretory parameters responsible for the circulating hormone concentration time course. To characterize the nature of GH secretory events leading to the changes in plasma $\mathrm{GH}$ concentrations in uremia, a multiparameter deconvolution technique was used to calculate the number, duration, amplitude, and mass of underlying GH secretory bursts and to estimate simultaneously the subject-specific half-life of GH in children with preterminal CRF and ESRD. An age-, gender-, and body mass-matched control group of children with ISS and normal renal function was studied for comparison. The latter approach was chosen, because a former investigation in a large group of children with ISS using the same deconvolution technique did not elucidate any differences in the overall dynamics and amounts of GH secretion and clearance in ISS children compared with physiologic patterns observed in prepubertal children of normal height (12). Accordingly, the current paradigm was used to provide for the first time a mechanistic investigation of the neuroendocrine pathophysiology underlying altered pulsatile $\mathrm{GH}$ release in prepubertal children with ESRD.

\section{METHODS}

Patients. Spontaneous nocturnal GH secretion and stimulated $\mathrm{GH}$ secretion in response to an arginine infusion were studied in 12 children with ISS (10 boys, two girls), 11 children with preterminal CRF (seven boys, four girls), and 12 children with ESRD (seven boys, five girls). All subjects were prepubertal, i.e. in Tanner genital and pubic hair stage I (13). Children with ISS were defined by 1 ) plasma GH concentrations $>10 \mathrm{mg} / \mathrm{L}$ either during spontaneous nocturnal $\mathrm{GH}$ secretion or after pharmacologic stimulation, 2) height $\leq 2 \mathrm{SD}$ below age- and sex-matched normative values, and 3) exclusion of identifiable endocrine, metabolic, genetic, systemic, or psychologic causes of short stature. Specifically, the children had normal assessments of serum electrolytes, serum creatinine, blood urea nitrogen, creatinine clearance, erythrocyte sedimentation rate, complete blood count, serum thyroxine, free thyroxine, triiodothyronine, and thyroid-stimulating hormone, and normal urinalysis.

Children with preterminal CRF and ESRD were selected on the basis of the following criteria: 1 ) preterminal CRF (GFR $<$ $70 \mathrm{~mL} / \mathrm{min} / 1.73 \mathrm{~m}^{2}$ ) or ESRD on regular continuous ambulatory peritoneal dialysis; 2) growth retardation defined as a height SD score for chronologic age $\leq-2$ and a height velocity SD score for chronologic age $\leq 0$, using the First Zurich Longitudinal Growth Study as a reference (14); 3) chronologic age $>1.5 \mathrm{y} ; 4$ ) no evidence of hypothyroidism, hypoparathyroidism, diabetes insipidus, or Addison's disease; 5) no history of diabetes mellitus, malignancy, or clinically significant cardiac abnormality; 6) no previous treatment with anabolic or sex steroids, recombinant human GH, or recombinant human erythropoietin. Clinical characteristics of controls with ISS and patients with preterminal CRF and ESRD are given in Table 1 . The primary renal disease in children with preterminal CRF and ESRD was renal dysplasia/hypoplasia in eight, chronic glomerulopathy in six, obstructive or reflux uropathy in four, chronic interstitial nephritis in one, and other diseases in four. Patients with preterminal CRF and ESRD received medications consisting of vitamin $\mathrm{D}$, water-soluble vitamins, oral phosphate binders, and oral sodium bicarbonate; antihypertensive treatment was given in 12 subjects. No patients received clonidine, glucocorticoids, or other immunosuppressive drugs.

Height and weight were measured in all subjects with standardized equipment and techniques (15). To estimate the degree of obesity, the BMI was calculated using this formula: weight $(\mathrm{kg}) /$ height $^{2}\left(\mathrm{~m}^{2}\right)$ (Quetelet index). To obtain ageindependent estimates of body size and mass, height, height velocity, and BMI (after logarithmic transformation) were converted to SD score values, related to age- and genderspecific means and SD of European reference populations (14, 16). Because all patients were growth-retarded, height age rather than chronologic age was used in the calculation of BMI $\mathrm{SD}$ score to assign each individual to an age class in the reference population. Bone age was assessed by radiographs of the left hand within 3 mo of the date of the hormone study using the Tanner-Whitehouse radioulnar score (17).

GFR was measured in children with preterminal CRF using single-injection inulin clearance, as described previously (18). The accuracy of single-injection inulin clearances in children with preterminal CRF was previously validated by comparison with steady state ${ }^{111}$ In-diaminotetraethylpentacetic acid plasma clearance (19). GFR in controls with ISS was estimated according to Schwartz et al. $(20)$ : GFR $=0.55 \times$ height $(\mathrm{cm}) /$ serum creatinine concentration $(\mathrm{mg} / \mathrm{dL})$. In patients with ESRD, no attempt was made to measure residual GFR, which is usually in the very low range between 5 and $10 \mathrm{~mL} / \mathrm{min} / 1.73$ $\mathrm{m}^{2}$.

Study protocol. The children were studied after informed parental consent before initiation of a therapeutic trial with recombinant human $\mathrm{GH}$. The study protocol was approved by the local ethics committee. Each participant underwent a detailed clinical history and a complete physical examination. The children were admitted to the hospital $1 \mathrm{~d}$ before the tests were performed to allow adaptation to the hospital environment. On the day before examination of nocturnal GH secretion, children were allowed to eat regular meals at 0800,1200 , and $1700 \mathrm{~h}$. Patients with ESRD on continuous ambulatory peritoneal dialysis performed their regular fluid exchange during the night. An i.v. catheter was placed in a forearm vein for blood sampling at least $1 \mathrm{~h}$ before initiation of the study. Beginning at $2000 \mathrm{~h}, 0.5 \mathrm{~mL}$ blood was withdrawn at 20 -min intervals for $10 \mathrm{~h}$ until $0600 \mathrm{~h}$ the next morning. Patients remained in bed with lights and television off between 2100 and $0600 \mathrm{~h}$. To encourage normal sleep, nighttime samples were collected with the least possible disturbance of the children. Blood was collected into EDTA vials, and plasma was separated and frozen until assay. On the next morning, a GH 
stimulation test in response to arginine infusion was performed. Arginine hydrochloride $(0.5 \mathrm{~g} / \mathrm{kg}$ body weight) was administered i.v. over a period of $30 \mathrm{~min}$. Blood samples were obtained every $15 \mathrm{~min}$ for $2 \mathrm{~h}$ for the determination of plasma $\mathrm{GH}$ concentrations.

Assays. Plasma GH concentrations were determined in duplicate by an immunoradiometric assay (Medgenix Group s.a., Fleurus, Belgium). The detection limit was $0.1 \mathrm{mg} / \mathrm{L}$. The intraassay and interassay coefficients of variation for a $\mathrm{GH}$ concentration of $2.2 \pm 0.1 \mathrm{mg} / \mathrm{L}$ were 4.6 and $8.3 \%$, respectively, and for a GH concentration of $10.3 \pm 0.4 \mathrm{mg} / \mathrm{L}$ were 3.9 and $6.0 \%$, respectively. All samples from one child were studied in the same assay. Plasma IGF-I concentration (morning fasting sample) was determined after acid chromatography by RIA (21) with an antiserum provided by Drs. L. E. Underwood and J. J. Van Wyk, and distributed by the National Hormone and Pituitary Program (Baltimore, MD).

Deconvolution analysis. The deconvolution model applied in our study to estimate endogenous GH secretory patterns has been described in detail previously $(11,22,23)$. Deconvolution analysis permits quantitative estimates in each individual of hormone secretory parameters and subject-specific hormone half-life by analyzing a time series of plasma hormone concentrations and their dose-dependent intrasample variances (8-11). In this technique, we assume that the plasma $\mathrm{GH}$ concentration at any given instant reflects the interplay of four determinable secretory and clearance terms: 1 ) the number and locations, 2) the amplitudes, and 3) the durations of all significant GH secretory bursts, which are acted upon by 4) endogenous subject-specific clearance kinetics. The GH disappearance function was defined by a subject-specific monoexponential half-life, fitted simultaneously with the various secretion parameters.

The following features of GH secretion and clearance were calculated: 1 ) the half-duration (duration at half-maximal amplitude) of GH secretory bursts; 2) the amplitudes (maximal rates of individual $\mathrm{GH}$ secretory bursts); 3) the number of secretory bursts; and 4) the GH half-life. The mass of GH secreted per burst is the analytical integral of the resolved secretory burst, and the 10 -h production rate is the product of the total number of secretory bursts and the mean mass of $\mathrm{GH}$ released per burst (8-11). In principle, an additional component of basal (tonic) secretion can also be introduced. Because, in the case of $\mathrm{GH}$, plasma concentrations in conventional immunoradiometric assays usually drop to undetectable values during extended interpulse intervals, the maximal basal secretion component was set constant and equal to the lower limit of detection. Thus, only secretion above the detection limit was estimated. GH clearance was modeled as a onecompartment model, with a unique rate constant for each subject, because the 20 -min sampling paradigm used in our study does not provide sufficient information for assessment of the first phase distribution.

Statistical analyses. Data are given as means \pm SEM. One-way analysis of variance, and the nonparametric KruskalWallis test, followed by pair-wise multiple comparisons (Student-Newman-Keuls method) were used for normal and nonGaussian distributed variables, respectively, as defined by the
Shapiro-Wilk test (24). Correlations between variables were assessed using univariate linear regression analysis. $p<0.05$ was accepted as statistically significant.

\section{RESULTS}

The clinical characteristics of patients with preterminal CRF and ESRD and controls with ISS are summarized in Table 1. Age, weight, height, height velocity, and BMI, whether expressed in absolute terms or related to age- and gender-specific normative values (SD score), did not differ significantly between controls, children with preterminal CRF, and children with ESRD. Bone age was delayed to a comparable degree in children with ISS and preterminal CRF and ESRD. Hence, the three groups were comparable in age, growth, body composition, and developmental retardation. By definition, GFR was normal in children with ISS and markedly reduced in children with preterminal CRF (Table 1).

The 10 -h profiles of pulsatile plasma GH concentrations and the deconvolution estimates of underlying GH secretion are illustrated in Figure 1 for one control subject with ISS, one patient with preterminal CRF, and one patient with ESRD. The measured plasma GH concentrations are depicted as discrete data points in the upper panels. The lower panels of Figure 1 show the deconvolution-resolved computed pituitary GH secretion rates, their amplitudes (maximal rate of $\mathrm{GH}$ secretion attained per burst) at different time points, and their halfdurations (duration of the $\mathrm{GH}$ secretory burst at half-maximal amplitude). The calculated reconvolution curves predicted are shown as continuous curves in the upper panels. Pulsatile $\mathrm{GH}$ release over the 10 -h observation period was evident both in subjects with ISS and patients with preterminal CRF and ESRD. In the control subject with ISS, GH secretion occurred in three secretory bursts per observation period, whereas the patient with ESRD clearly showed more frequent GH secretory events.

Deconvolution analysis revealed that the mean endogenous GH half-life in patients with ESRD was markedly higher than that in controls with ISS (Fig. 2 and Table 2); the GH half-life in patients with preterminal CRF was shorter than the value in ESRD patients with no residual renal function but significantly higher than in controls. When the data of patients with preterminal CRF and controls were plotted together, a highly significant inverse linear correlation between GFR and GH half-life was observed (Fig. 3).

The mean number of detectable GH secretory bursts per 10-h observation period in patients with ESRD was higher than in controls and in patients with preterminal CRF (Table 2). The interburst interval, the half-duration of GH secretory bursts (duration in minutes at half-maximal amplitude), and the mean GH secretory burst amplitude, i.e. the maximal rates of secretion attained within the bursts, were not different statistically between renal failure patients and controls. Also, the mean GH secretory burst mass (calculated as the area under the computer-resolved GH secretory burst) was not statistically different between the groups (Table 2).

The GH production rate is the product of the mean mass of GH secreted per burst and the number of secretory bursts per 
Table 1. Clinical characteristics, plasma IGF-I concentration, and GFR of controls with ISS and patients with preterminal CRF and ESRD

\begin{tabular}{|c|c|c|c|}
\hline Parameter & $\begin{array}{l}\text { Controls with ISS } \\
\quad(n=12)\end{array}$ & $\begin{array}{l}\text { Preterminal CRF } \\
\quad(n=11)\end{array}$ & $\begin{array}{c}\text { ESRD } \\
(n=12)\end{array}$ \\
\hline Age (y) & $\begin{array}{l}7.3 \pm 0.7 \\
(4.3-11.8)\end{array}$ & $\begin{array}{l}6.4 \pm 1.1 \\
(1.7-12.8)\end{array}$ & $\begin{array}{l}6.3 \pm 1.2 \\
(2.3-14.3)\end{array}$ \\
\hline Bone age (y) & $\begin{array}{l}5.1 \pm 0.7 \\
(2.4-10.0)\end{array}$ & $\begin{array}{l}4.3 \pm 0.9 \\
(0.9-10.0)\end{array}$ & $\begin{array}{l}4.2 \pm 0.9 \\
(1.0-11.8)\end{array}$ \\
\hline Weight (kg) & $\begin{array}{c}17.2 \pm 1.4 \\
(9.4-24.7)\end{array}$ & $\begin{array}{c}16.1 \pm 2.2 \\
(7.8-33.1)\end{array}$ & $\begin{array}{c}14.7 \pm 1.6 \\
(9.0-26.4)\end{array}$ \\
\hline Height $(\mathrm{cm})$ & $\begin{array}{c}108.3 \pm 3.5 \\
(86.0-129.5)\end{array}$ & $\begin{array}{c}102.5 \pm 6.1 \\
(76.0-141.3)\end{array}$ & $\begin{array}{l}99.5 \pm 5.1 \\
(75.5-133.0)\end{array}$ \\
\hline Height SD score-CA & $\begin{array}{l}-3.17 \pm 0.32 \\
(-5.90 \text { to }-2.10)\end{array}$ & $\begin{array}{c}-3.12 \pm 0.30 \\
(-4.66 \text { to }-2.00)\end{array}$ & $\begin{array}{l}-3.63 \pm 0.40 \\
(-7.6 \text { to }-2.00)\end{array}$ \\
\hline Height velocity $(\mathrm{cm} / \mathrm{y})$ & $\begin{array}{l}4.5 \pm 0.3 \\
(3.0-6.7)\end{array}$ & $\begin{array}{l}6.3 \pm 1.3 \\
(3.0-11.0)\end{array}$ & $\begin{array}{l}4.3 \pm 0.8 \\
(0.0-9.8)\end{array}$ \\
\hline Height velocity SD score-Ca & $\begin{array}{l}-1.5 \pm 0.3 \\
(-2.7 \text { to }-0.2)\end{array}$ & $\begin{array}{l}-1.5 \pm 0.5 \\
(-3.6 \text { to } 0)\end{array}$ & $\begin{array}{c}-2.4 \pm 0.4 \\
(-6.0 \text { to }-0.7)\end{array}$ \\
\hline BMI $\left(\mathrm{kg} / \mathrm{m}^{2}\right)$ & $\begin{array}{l}14.4 \pm 0.5 \\
(10.8-17.2)\end{array}$ & $\begin{array}{l}14.6 \pm 0.4 \\
(13.2-17.8)\end{array}$ & $\begin{array}{l}14.4 \pm 0.9 \\
(13.0-16.0)\end{array}$ \\
\hline BMI SD score & $\begin{array}{l}-1.36 \pm 0.56 \\
(-5.57 \text { to }+1.40)\end{array}$ & $\begin{array}{c}-1.72 \pm 0.27 \\
(-3.31 \text { to }+0.05)\end{array}$ & $\begin{array}{c}-1.57 \pm 0.25 \\
(-2.76 \text { to }-0.06)\end{array}$ \\
\hline IGF-I (ng/mL) & $\begin{array}{c}93.0 \pm 20.6 \\
(8.0-194)\end{array}$ & $\begin{array}{l}87.7 \pm 33.5 \\
(18.9-412)\end{array}$ & $\begin{array}{c}126 \pm 24.4 \\
(41.0-331)\end{array}$ \\
\hline IGF-I SD score & $\begin{array}{l}-0.66 \pm 0.23 \\
(-1.62 \text { to }+0.31)\end{array}$ & $\begin{array}{c}-0.82 \pm 0.36 \\
(-1.88 \text { to }+1.67)\end{array}$ & $\begin{array}{c}-0.21 \pm 0.34 \\
(-2.90 \text { to }+1.55)\end{array}$ \\
\hline GFR $\left(\mathrm{mL} / \mathrm{min} / 1.73 \mathrm{~m}^{2}\right)$ & $\begin{array}{c}112 \pm 4.8 \\
(89.3-144)\end{array}$ & $\begin{array}{c}29.5 \pm 6.3^{*} \\
(9.3-66.0)\end{array}$ & \\
\hline
\end{tabular}

Data are mean \pm SEM. Ranges are given in parentheses. CA, chronologic age.

${ }^{*} p<0.001 v s$ controls. GFR was estimated according to Schwartz in controls with ISS and measured by single-injection inulin clearances in children with preterminal CRF.

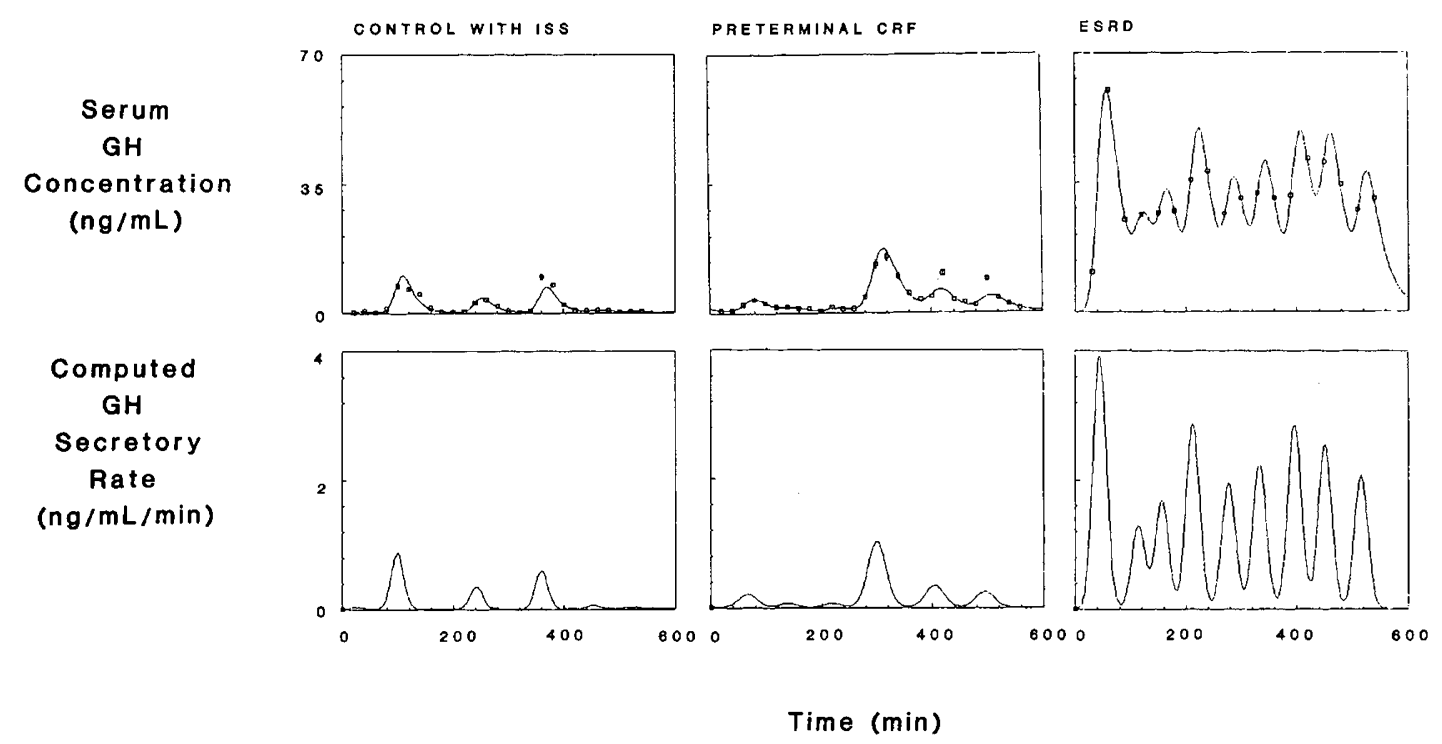

Figure 1. Illustrative profiles of pulsatile plasma GH concentrations in one control subject with ISS, one child with preterminal CRF, and one child with ESRD. The upper panels depict the serial plasma GH concentrations over time, as measured by immunoradiometric assay of plasma derived from blood collected at 20-min intervals for $10 \mathrm{~h}$, and the deconvolution-predicted curves, which closely approximate the experimental data points. The lower panels show the deconvolution-calculated GH secretory bursts over a period of $10 \mathrm{~h}$. Note the presence of an increased number of secretory bursts in the child with ESRD.

$10 \mathrm{~h}$. Mainly as a result of an increased number of $\mathrm{GH}$ secretory bursts, the mean $\mathrm{GH}$ production rate in subjects with ESRD was significantly higher than that in subjects with preterminal CRF and tended to be higher than in controls with ISS (Table 2). This difference remained statistically significant when the production rate of endogenous $\mathrm{GH}$ per $10 \mathrm{~h}$ was expressed per unit body surface area (Table 2). The amount of total $\mathrm{GH}$ secretion per $10 \mathrm{-h}$ period was calculated as the product of the calculated secretion rate $(\mathrm{mg} / \mathrm{L}$ distribution volume $/ 10 \mathrm{~h}$ ) and an estimated distribution volume of $7.9 \%$ body weight (25). A linear relationship was found between total $\mathrm{GH}$ secretion per $10 \mathrm{~h}$ and age in controls and in patients with preterminal CRF but not in patients with ESRD (Fig. 4).

As expected from the significantly elevated GH half-life in ESRD, both mean and integrated plasma $\mathrm{GH}$ concentrations were significantly elevated in ESRD compared with preterminal CRF and controls with ISS (Table 2). Despite these marked differences in mean $\mathrm{GH}$ concentrations between controls and 


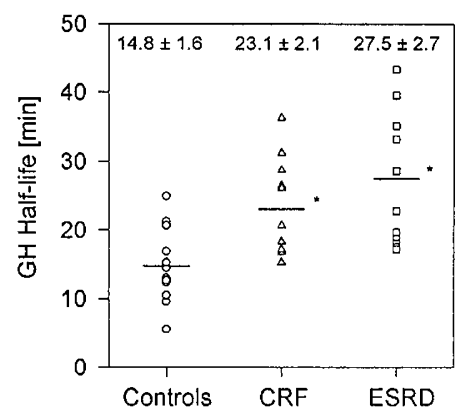

Figure 2. Comparison of calculated endogenous GH half-life (by deconvolution analysis) in controls with ISS $(n=12)$, children with preterminal CRF $(n=11)$, and children with $\operatorname{ESRD}(n=12)$. The GH half-life in patients with ESRD and in patients with preterminal CRF was significantly higher $\left({ }^{*}, p<\right.$ 0.001) than in controls with ISS.

children with ESRD, plasma total IGF-I levels in the two groups were indistinguishable from each other (Table 1).

The results of plasma $\mathrm{GH}$ concentrations stimulated by arginine infusion are shown in Table 3. Basal plasma GH concentrations in ESRD were significantly higher than in controls with ISS and children with preterminal CRF. The maximal plasma GH concentration as well as the mean plasma GH concentration during the arginine infusion were significantly higher in patients with ESRD than in those with preterminal CRF and in controls with ISS.

\section{DISCUSSION}

Our study demonstrates that the number of detectable GH secretory bursts per observation period in prepubertal children with ESRD is significantly higher compared with age- and sex-matched children with ISS and comparable body composition compared with children with preterminal CRF and therefore a milder degree of uremia. This abnormality was specific, because the secretory burst amplitude, the secretory burst half-duration, and the mass of GH secreted per burst were not statistically different between the groups. Mainly as a result of an increased number of $\mathrm{GH}$ secretory bursts, the mean $\mathrm{GH}$ production rate in children with ESRD exceeded the $\mathrm{GH}$ production rate in children with preterminal CRF and tended to be higher than in controls with ISS. The GH production rate in children with preterminal CRF, although numerically lower, was not significantly different from that in controls with ISS. This unexpected finding is probably due to the broad spectrum of GH secretion that was apparent in all three groups (Table 2) and that is also observed in children of normal stature under physiologic conditions (26). Interestingly, the physiologic increase of total $\mathrm{GH}$ production at least during prepubertal maturation (26) seems to be disrupted in severely uremic children, inasmuch as the linear relation between total $\mathrm{GH}$ production and age observed in controls with ISS and in children with preterminal CRF was not apparent in patients with ESRD (Fig. 4).

In our study, we chose a nocturnal sampling period of $10 \mathrm{~h}$ for both controls with ISS and children with preterminal CRF and ESRD, because the majority of daily $\mathrm{GH}$ secretion (65\%) in prepubertal children occurs during the night (26), and a more extensive sampling period appeared not to be justified in view of the anemia and limited blood volume of growth-retarded children. A similar relation between daytime (36\%) and nighttime $(64 \%)$ pulsatile $\mathrm{GH}$ plasma concentration was observed in children with ESRD (4). Also, in adults with ESRD, a preserved nyctohemeral variation in $\mathrm{GH}$ secretion was reported (27). We therefore assume that the nocturnal GH secretion examined in our study is representative of that obtained during 24-h sampling.

GH secretion is subject to complex metabolic regulation by body composition, sex steroid hormones, puberty, and age, among other factors (28). We therefore sought to compare GH

Table 2. Deconvolution analysis of spontaneous nocturnal GH secretion and clearance in controls with ISS and patients with preterminal

\begin{tabular}{|c|c|c|c|c|}
\hline \multicolumn{5}{|c|}{$C R F$ and ESRD } \\
\hline Parameter & $\begin{array}{l}\text { Controls with ISS } \\
\quad(n=12)\end{array}$ & $\begin{array}{l}\text { Preterminal CRF } \\
\quad(n=11)\end{array}$ & $\begin{array}{c}\text { ESRD } \\
(n=12)\end{array}$ & Statistics \\
\hline Plasma GH half-life (min) & $\begin{array}{c}14.8 \pm 1.6 \\
(5.6-24.9)\end{array}$ & $\begin{array}{l}23.1 \pm 2.1 \\
(15.3-36.3)\end{array}$ & $\begin{array}{l}27.5 \pm 2.7 \\
(17.2-43.3)\end{array}$ & $\begin{array}{r}p<0.001, \text { ESRD vs controls, } \\
\text { preterminal CRF vs controls }\end{array}$ \\
\hline Number of GH secretory bursts/10 h & $\begin{array}{l}5.9 \pm 0.4 \\
(3-9)\end{array}$ & $\begin{array}{l}6.4 \pm 0.5 \\
(4-9)\end{array}$ & $\begin{array}{l}8.1 \pm 0.4 \\
(7-10)\end{array}$ & $\begin{array}{l}p<0.005, \text { ESRD vs controls } \\
\text { and preterminal CRF }\end{array}$ \\
\hline Interburst interval (min) & $\begin{array}{c}82.1 \pm 10.1 \\
(59-188)\end{array}$ & $\begin{array}{r}78.2 \pm 4.9 \\
(59-113)\end{array}$ & $\begin{array}{c}70.1 \pm 3.5 \\
(53-90)\end{array}$ & NS \\
\hline Secretory burst amplitude (mg/L/min) & $\begin{array}{l}1.11 \pm 0.34 \\
(0.18-4.6)\end{array}$ & $\begin{array}{l}0.75 \pm 0.26 \\
(0.14-3.0)\end{array}$ & $\begin{array}{l}0.98 \pm 0.23 \\
(0.26-2.4)\end{array}$ & NS \\
\hline Secretory burst half-duration (min) & $\begin{array}{l}23.9 \pm 2.2 \\
(10.6-33.0)\end{array}$ & $\begin{array}{l}22.9 \pm 3.4 \\
(3.3-38.8)\end{array}$ & $\begin{array}{l}29.0 \pm 4.6 \\
(4.0-47.3)\end{array}$ & NS \\
\hline GH mass secreted/burst (mg/L) & $\begin{array}{r}23.9 \pm 5.2 \\
(4.3-65.4)\end{array}$ & $\begin{array}{c}11.0 \pm 2.1 \\
(4.7-28.0)\end{array}$ & $\begin{array}{r}26.4 \pm 8.2 \\
(5.2-97.5)\end{array}$ & NS \\
\hline $\begin{array}{l}\text { GH production rate } / \mathrm{L} \text { distribution volume } \\
(\mathrm{mg} / \mathrm{L} / 10 \mathrm{~h})\end{array}$ & $\begin{array}{r}129 \pm 27.7 \\
(39-392)\end{array}$ & $\begin{array}{c}66.2 \pm 11.4 \\
(25-168)\end{array}$ & $\begin{array}{r}202 \pm 56.6 \\
(36-683)\end{array}$ & $\begin{array}{c}p<0.05, \text { ESRD } v s \\
\text { preterminal CRF }\end{array}$ \\
\hline $\begin{array}{l}\text { GH production } / \mathrm{m}^{2} \text { body surface area } \\
\left(\mathrm{mg} / \mathrm{m}^{2} / 10 \mathrm{~h}\right)\end{array}$ & $\begin{array}{l}244 \pm 53.7 \\
(73.0-766)\end{array}$ & $\begin{array}{l}124 \pm 22.3 \\
(41.0-308)\end{array}$ & $\begin{array}{l}357 \pm 98.0 \\
(72.3-1110)\end{array}$ & $\begin{array}{l}p<0.05, \text { ESRD } v s \\
\text { preterminal CRF }\end{array}$ \\
\hline Mean $\mathrm{GH}$ concentration $(\mathrm{mg} / \mathrm{L})$ & $\begin{array}{l}4.4 \pm 0.6 \\
(1.8-9.3)\end{array}$ & $\begin{array}{l}4.6 \pm 0.5 \\
(2.9-7.9)\end{array}$ & $\begin{array}{c}11.3 \pm 2.4 \\
(2.2-32)\end{array}$ & $\begin{array}{l}p<0.005, \text { ESRD } v s \text { controls } \\
\text { and } v s \text { preterminal CRF }\end{array}$ \\
\hline Integrated $\mathrm{GH}$ concentration $(\mathrm{mg} / \mathrm{L} / \mathrm{min})$ & $\begin{array}{c}2280 \pm 319 \\
(952-4570)\end{array}$ & $\begin{array}{c}2360 \pm 312 \\
(887-4560)\end{array}$ & $\begin{array}{l}6150 \pm 1270 \\
(1310-16,600)\end{array}$ & $\begin{array}{c}p<0.02, \text { ESRD } v s \text { controls } \\
\text { and } v s \text { preterminal CRF }\end{array}$ \\
\hline
\end{tabular}

Data are mean \pm SEM. Ranges are given in parentheses. The volume term $(\mathrm{L})$ refers to unit distribution value for $\mathrm{GH}$. 


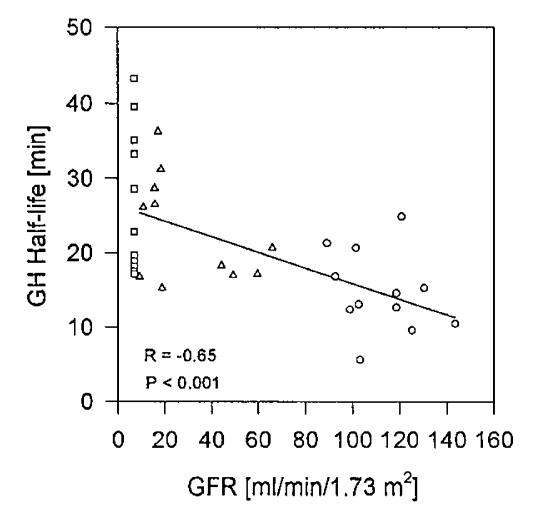

Figure 3. Relationship between GFR and estimated endogenous GH half-life in controls with ISS $(\boldsymbol{\bullet})$, children with preterminal $\mathrm{CRF}(\boldsymbol{\Lambda})$, and children with ESRD ( $\square$ ). GFR in children with ESRD, which usually varies between 5 and $10 \mathrm{~mL} / \mathrm{min} / 1.73 \mathrm{~m}^{2}$, was arbitrarily entered as $7 \mathrm{~mL} / \mathrm{min} / 1.73 \mathrm{~m}^{2}$. The regression was calculated from the pooled data of controls with ISS and patients with preterminal CRF. A highly significant inverse linear correlation was found $(r=-0.65, p<0.001)$.
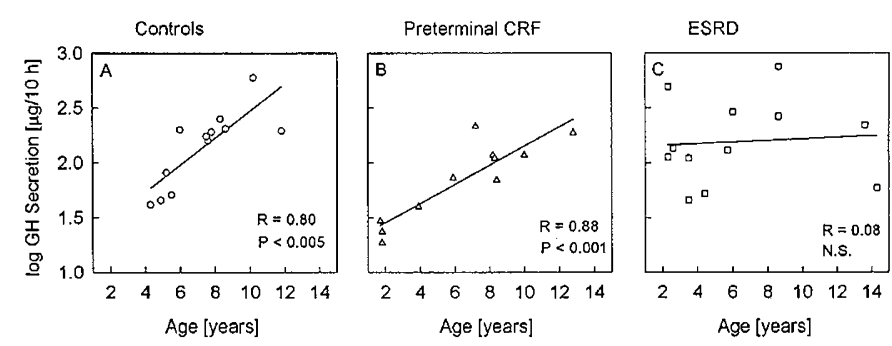

Figure 4. Relationship between chronologic age and calculated total $\mathrm{GH}$ secretion rate in controls with ISS $(A)$, children with preterminal CRF $(B)$, and children with ESRD $(C)$. The 10-h GH secretion values were determined for each subject by simultaneous multiple-parameter deconvolution analysis of their 10-h plasma GH concentration time series. The calculated GH secretion rate $(\mathrm{mg} / \mathrm{L}$ distribution volume/10 $\mathrm{h}$ ) was multiplied by an assumed distribution volume of $7.9 \%$ body weight (25) to obtain the illustrated estimates. The $\mathrm{GH}$ secretion values depicted were logarithmically transformed.

secretion in children with preterminal CRF and ESRD with a suitably matched control group. There were ethical concerns to perform overnight blood sampling in normal controls. Accordingly, a group of children with ISS with similar age and anthropometric features was used for comparison. A former extended investigation in 20 children with ISS had found that the mean number, amplitude, mass, and duration of spontaneous GH secretory bursts and the mean half-life of endogenous $\mathrm{GH}$ do not differ between groups of normally growing boys and boys with ISS (12). The children with ISS in our study had inclusion criteria and clinical features similar to those in the former study and a similar broad spectrum of GH secretion, as also observed under physiologic conditions in children of normal stature (26). We therefore assume that this group of children with ISS in our study represents a GH secretory pattern close to that of normal children. The slight preponderance of boys in the group of ISS children compared with children with preterminal CRF and ESRD is unlikely to affect the comparison between the groups, because gender does not significantly influence spontaneous GH secretion in prepubertal normal short stature children (29). Thus, the comparison between children with preterminal CRF and ESRD and con- trols with ISS is likely to reflect the differences in GH secretory behavior, which can be related specifically to the metabolic changes of the uremic milieu.

The increased number of GH secretory bursts in prepubertal children with ESRD in our study is consistent with recent data in adult patients with ESRD on hemodialysis (27). Using the same deconvolution procedure used here, a comparably increased frequency of detectable GH secretory bursts was observed. In contrast, a recent study in a combined group of peripubertal children with preterminal CRF and ESRD found no difference in the number of GH secretory bursts compared with controls (30). The latter discrepancy with results in our study may be explained by the experimental protocol (same sampling and assay conditions in our study, but hormone determinations using two different assays followed by mathematical conversion of the results in Ref. 30) and by differences in body composition of controls and uremic subjects in our study compared with Ref. 30 (low normal BMI SD score both in controls and uremic children in our study versus highnormal BMI SD score in Ref. 30). Body composition appears to be an important physiologic modulator and negative determinant of spontaneous $\mathrm{GH}$ secretion both in normal children (26) and adults (31). Consequently, our control and uremic volunteers were matched for BMI to allow valid comparisons.

The mechanism responsible for increased GH secretion in the uremic state is not known. The pulsatile secretion of GH is regulated by the reciprocal interplay of hypothalamic GHRH and somatostatin (32-35) and by responsivity of the somatotrope cells to these regulatory peptides (28). In general, the amount of GHRH released at any given level of somatostatin tone determines the amount of $\mathrm{GH}$ released per secretory episode, and the pattern of somatostatin action determines the frequency and duration of the GH secretory bursts (36-38). The finding in our study of an increased frequency of detectable GH secretory bursts is consistent with reduced somatostatinergic inhibitory tone. This hypothesis cannot be directly verified, because no information about the local hypothalamic production of this peptide in humans with CRF is available. Theoretically, a decrease in somatostatin tone could be due to reduced hypothalamic or pituitary feedback actions of IGF-I or GH itself, as well as alterations to other feedback regulators of the somatotropic axis. IGF-I directly inhibits pituitary $\mathrm{GH}$ secretion and under some conditions also stimulates hypothalamic somatostatin release (39). Circulating immunoreactive IGF-I levels were normal in our study and in former reports in adults and children with preterminal CRF and ESRD $(30,41)$. However, IGF bioactivity is reduced in uremic plasma (41) mainly due to an accumulation of IGF binding proteins that are normally removed from the circulation by renal filtration. Thus, reduced IGF bioactivity presumably leads to a reduced feedback potency of circulating and local IGF-I (42), resulting in disinhibition of the somatotropic axis with consequent increases in the frequency of detectable GH secretory bursts. Whether decreased IGF-I synthesis in the hypothalamus or pituitary gland also increases $\mathrm{GH}$ secretion by paracrine mechanisms (43) is not known in the uremic state. In addition, GH itself negatively regulates the somatotropic axis by inhibition of GHRH release through a somatostatin-dependent, short-loop 
Table 3. Stimulated GH concentrations in response to arginine infusion in controls with ISS and patients with preterminal CRF and ESRD

\begin{tabular}{|c|c|c|c|c|}
\hline Parameter & $\begin{array}{l}\text { Controls with ISS } \\
\qquad(n=12)\end{array}$ & $\begin{array}{l}\text { Preterminal CRF } \\
\qquad(n=11)\end{array}$ & $\begin{array}{c}\text { ESRD } \\
(n=12)\end{array}$ & Statistics \\
\hline Basal plasma GH concentration $(\mathrm{mg} / \mathrm{L})$ & $0.7 \pm 0.2$ & $3.2 \pm 0.4$ & $13.8 \pm 3.9$ & $\begin{array}{l}p<0.001, \text { ESRD } v s \text { controls } \\
\text { and } v s \text { preterminal CRF }\end{array}$ \\
\hline Maximal plasma $\mathrm{GH}$ concentration $(\mathrm{mg} / \mathrm{L})$ & $13.9 \pm 2.7$ & $12.4 \pm 1.6$ & $38.0 \pm 7.2$ & $\begin{array}{l}p<0.01, \text { ESRD } v s \text { controls and } \\
v s \text { preterminal CRF }\end{array}$ \\
\hline Mean plasma $\mathrm{GH}$ concentration $(\mathrm{mg} / \mathrm{L})$ & $4.6 \pm 0.9$ & $6.2 \pm 0.6$ & $23.0 \pm 6.3$ & $\begin{array}{l}p<0.005, \text { ESRD } v s \text { controls } \\
\text { and } v s \text { preterminal CRF }\end{array}$ \\
\hline
\end{tabular}

feedback mechanism (43). Thus, the enhanced number of GH secretory bursts, despite increased circulating GH concentrations in uremia, points to a tissue resistance to the actions of $\mathrm{GH}$ at the level of the hypothalamus. This hypothesis is consistent with other signs of hyporesponsiveness to the actions of GH in uremia, viz. reduced longitudinal growth (1) and inadequate stimulation of hepatic IGF-I secretion (44).

Recent studies in the uremic rat model have sought to identify the molecular mechanisms that alter the neuroendocrine control of GH secretion in renal failure. Isolated somatotropes from rats with preterminal CRF retained normal responsiveness to GHRH in vitro indicating that the hypothalamus, rather than the pituitary gland, is the major site of dysregulation of GH secretion in uremia (45). In the hypothalamus, lower GHRH mRNA concentrations and an unchanged hypothalamic somatostatin mRNA content were found in uremic animals (46). Detailed data about GH secretion in the uremic rat model are not available, although metabolic acidosis in such animals inhibits pulsatile GH secretion (47). Notably, the regulation of $\mathrm{GH}$ secretion in the rat cannot be readily applied to humans, because under various pathologic conditions such as malnutrition and diabetes mellitus, GH secretion is inversely regulated in rats compared with humans. For example, whereas GH secretion is increased in human subjects with malnutrition (48) and diabetes mellitus (49), it progressively declines both in food-deprived rats (50) and in experimentally diabetic rats (51). Thus, reduced hypothalamic GHRH mRNA content in uremic rats is by no means contradictory to increased numbers of GH secretory bursts in uremic patients.

Whether the altered pulsatile pattern of $\mathrm{GH}$ secretion in uremia contributes to the reduced tissue response to $\mathrm{GH}$ is not known. In general, regular bursts of $\mathrm{GH}$ release seem to be important in the physiologic activation of certain target tissues. For example, rates of linear growth and cartilage and liver concentrations of mRNA transcripts of IGF-I are increased more effectively by pulsatile i.v. GH infusion to hypophysectomized rats than continuous $\mathrm{GH}$ infusion $(52,53)$. Indeed in experimental animals, constant exposure to $\mathrm{GH}$ can induce down-regulation of tissue $\mathrm{GH}$ receptors (54). In the uremic rat model, reduced hepatic $\mathrm{GH}$ receptor gene expression was recently demonstrated as a possible molecular mechanism of GH hyporesponsiveness in the uremic state (55). Accordingly, one can speculate that increased mean GH plasma concentrations in uremia may contribute to or result from downregulation of the hepatic $\mathrm{GH}$ receptor.

In our study, the mean half-life of endogenous $\mathrm{GH}$ in patients with ESRD was twice as high as in controls with ISS.
Patients with preterminal CRF and residual renal function also showed a significant elevation of their estimated GH half-lives, but to a lesser extent than patients with no residual renal function. The linear inverse correlation between GFR and endogenous GH half-lives is consistent with the concept that the kidneys are a major route of elimination of $\mathrm{GH}$ from the circulation in humans. Our estimates of endogenous GH halflives are similar to the half-times of exogenous recombinant human GH reported recently in subjects with normal and reduced renal function during pharmacologic suppression of endogenous GH secretion (6). It is unlikely that peritoneal dialysis during blood sampling in ESRD patients influenced their GH plasma concentrations or respective half-lives, because a previous study in adult patients on peritoneal dialysis demonstrated that the peritoneal losses of $\mathrm{GH}$ that occur during peritoneal dialysis are very low and do not affect GH serum concentration (56).

In conclusion, our study demonstrates that the number of GH secretory bursts in prepubertal children with ESRD exceeds that of age-, sex-, and BMI-matched controls with ISS and patients with preterminal CRF. We speculate that this increase in the number of $\mathrm{GH}$ secretory bursts results from attenuated bioactive IGF-I or GH feedback of the somatotropic axis. Increased GH half-life, in concert with an increase in $\mathrm{GH}$ production in some individuals with ESRD, leads to a 2.5-fold increase of mean plasma GH concentrations in children with ESRD. However, these increased circulating GH levels do not induce a commensurate rise in circulating IGF-I concentrations. This dissociation of the normal relationship between circulating GH and IGF-I plasma levels suggests an insensitivity to the action of GH in the uremic state, at least in those target organs that contribute predominantly to circulating IGF-I levels, e.g. the liver (55).

Acknowledgment. The authors thank Judith Pinkowski for her assistance in performing the hormone studies.

\section{REFERENCES}

1. Tönshoff B, Schaefer F, Mehls O 1990 Disturbance of growth hormone- insulin-like growth factor axis in uremia. Pediatr Nephrol 4:654-662

2. Samaan NA, Freeman RM 1970 Growth hormone levels in severe renal failure. Metabolism 19:102-113

3. Ramirez G, O'Neill Jr WM, Bloomer A, Jubiz W 1978 Abnormalities in the regulation of growth hormone in chronic renal failure. Arch Intern Med 138:267-271

4. Hokken-Koelega ACS, Hackeng WHL, Stijnen T, Wit JM, De Muinck KeizerSchrama SMPF, Drop SLS 1990 Twenty-four-hour plasma growth hormone (GH) profiles, urinary GH excretion, and plasma insulin-like growth factor-I and -II levels in prepubertal children with chronic renal insufficiency and severe growth retardation. J Clin Endocrinol Metab 71:688-695

5. Schaefer F, Hamill G, Stanhope R, Preece MA, Schärer K, Cooperative Study Group on Pubertal Development in Chronic Renal Failure 1991 Pulsatile growth hormone secretion in peri-pubertal patients with chronic renal failure. J Pediatr 119:568-577 
6. Haffner D, Schaefer F, Girard J, Ritz E, Mehls O 1994 Metabolic clearance rate of recombinant human growth hormone in health and chronic renal failure. J Clin Invest 93:1163-1171

7. Johnson V, Maack T 1977 Renal extraction, filtration, absorption, and catabolism of growth hormone. Am J Physiol 233:F185-F196

8. Veldhuis JD, Carlsson ML, Johnson ML 1987 The pituitary gland secretes in bursts: appraising the nature of glandular secretory impulses by simultaneous multipleparameter deconvolution of plasma hormone concentrations. Proc Natl Acad Sci USA $84: 7686-7690$

9. Veldhuis JD, Johnson ML 1992 Deconvolution analysis of hormone data. Methods Enzymol 210:539-575

10. Veldhuis JD, Iranmanesh A, Lizarralde G, Johnson ML 1989 Amplitude modulation of a burst-like mode of cortisol secretion gives rise to the nyctohemeral glucocorticoid rhythm in man. Am J Physiol 257:E6-E14

11. Veldhuis JD, Johnson ML, Bolton WK 1991 Analyzing pulsatile endocrine data in patients with chronic renal failure: a brief review of deconvolution techniques. Pediatr Nephrol 5:522-528

12. Veldhuis JD, Blizzard RM, Rogol AD, Martha Jr PM, Kirkland JL, Sherman BM, Genentech Collaborative Group 1992 Properties of spontaneous growth hormone secretory bursts and half-life of endogenous growth hormone in boys with idiopathic short stature. J Clin Endocrinol Metab 74:766-773

13. Tanner JM 1962 Growth and Adolescence. Blackwell Scientific Publications, Oxford, UK

14. Prader A, Largo RH, Molinari L, Issler C 1989 Physical growth of Swiss children from birth to 20 years of age. Helv Pediatr Acta [Suppl] 52:1-125

15. Cameron $\mathrm{N} 1984$ The Measurement of Human Growth. Croom Helm Ltd, London

16. Rolland-Cachera MF, Sempe M, Guilloud-Bataille M, Patois E, PequignotGuggenbuhl F, Fautrad V 1982 Adiposity indices in children. Am J Clin Nutr 36:178-184

17. Tanner JM, Whitehouse RH, Cameron N, Marshall WA, Healy MJR, Goldstein H 1983 Assessment of Skeletal Maturity and Prediction of Adult Height (TW2 Method), 2nd Ed. Academic Press, New York

18. Tönshoff B, Tönshoff C, Mehls O, Pinkowski J, Blum WF, Heinrich U, Stöver B, Gretz N 1992 Growth hormone treatment in children with preterminal chronic renal failure: no adverse effect on glomerular filtration rate. Eur J Pediatr 151:601-607

19. Schaefer F, Lindmayer F, Reinbold F, van Kaick G 1991 Validation of the singleinjection inulin clearance in pediatric patients. J Am Soc Nephrol 2:244(abstr)

20. Schwartz GJ, Haycock GB, Edelmann CM 1976 A simple estimate of glomerular filtration rate in children derived from body length and plasma creatinine. Pediatrics $58: 259-263$

21. Heinrich U, Ruland A, Hartmann K, Schönberg D 1987 Somatomedin C/IGF-I serum levels during childhood and adolescence. Pediatr Res 21:102(abstr)

22. Veldhuis JD, Faria A, Vance ML, Evans WS, Thorner MO, Johnson ML 1988 Contemporary tools for the analysis of episodic growth hormone secretion and clearance in vivo. Acta Paediatr Scand 347:63-82

23. Hartman ML, Faria ACS, Vance ML, Johnson ML, Thorner MO, Veldhuis JD 1991 Temporal structure of in vivo growth hormone secretory events in man. Am J Physiol 260:E101-E110

24. Zar JH 1984 Biostatistical Analysis. Prentice-Hall, Englewood Cliffs, NJ

25. Owens D, Srivastava MC, Tompkins CV, Nabarro JDN, Sonksen PH 1973 Studies on the metabolic clearance rate, apparent distribution space and plasma halfdisappearance time of unlabeled human growth hormone in normal subjects and in patients with liver disease, renal disease and diabetes mellitus. Eur $\mathrm{J}$ Clin Invest 3:284-294

26. Martha Jt PM, Gorman KM, Blizzard RM, Rogol AD, Veldhuis JD 1992 Endogenous growth hormone secretion and clearance rates in normal boys, as determined by deconvolution analysis: relationship to age, pubertal status, and body mass. J Clin Endocrinol Metab 74:336-344

27. Veldhuis JD, Iranmanesh A, Wilkowski MJ, Samojlik E 1994 Alterations in the neuroendocrine regulation of the somatotropic and lactotropic axes in uremia: amplified modes of growth hormone and prolactin secretion in men with end-stage renal failure. Eur $J$ Endocrinol (in press)

28. Iranmanesh A, Veldhuis JD 1992 Clinical pathophysiology of the somatotropic $(\mathrm{GH})$ axis in adults. In: Veldhuis JD (ed) Endocrinology and Metabolism Clinics of North America. WB Saunders, Philadelphia, pp 783-816

29. Abdenur JE, Solans CV, Smith MM, Carman C, Pugliese MT, Lifshitz F 1994 Body composition and spontaneous growth hormone secretion in normal short stature children. J Clin Endocrinol Metab 78:277-282

30. Schaefer F, Veldhuis JD, Stanhope R, Jones J, Schärer K, Cooperative Study Group on Pubertal Development in Chronic Renal Failure 1994 Alterations in growth hormone secretion and clearance in peripubertal boys with chronic renal failure and after renal transplantation. J Clin Endocrinol Metab 78:1298-1306

31. Iranmanesh A, Lizarralde G, Veldhuis JD 1991 Age and relative adiposity are specific negative determinants of the frequency and amplitude of growth hormone $(\mathrm{GH})$ secretory bursts and the half-life of endogenous $\mathrm{GH}$ in healthy men. J Clin Endocrinol Metab 73:1081-1088

32. Sato M, Takahara J, Fujioka Y, Niimi M, Irino S 1988 Physiological role of growth hormone $(\mathrm{GH})$-releasing factor and somatostatin in the dynamics of $\mathrm{GH}$ secretion in adult male rat. Endocrinology 123:1928-1933
33. Willoughby JO, Koblar S, Jervois PM, Menadue MF, Oliver JR 1983 Evidence that the regulation of growth hormone secretion is mediated predominantly by a growth hormone releasing factor. Neuroendocrinology 36:358-363

34. Plotsky PM, Vale W 1985 Patterns of growth hormone-releasing factor and somatostatin secretion into the hypophysial-portal circulation of the rat. Science 230:461465

35. Tannenbaum GS 1991 Neuroendocrine control of growth hormone secretion. Acta Paediatr Scand Suppl 372:5-16

36. Kraicer J, Sheppard MS, Luke J, Lussier B, Moor BC, Cowan JS 1988 Effect of withdrawal of somatostatin and growth hormone $(\mathrm{GH})$-releasing factor on $\mathrm{GH}$ release in vitro. Endocrinology 122:1810-1815

37. Weiss J, Cronin MJ, Thorner MO 1987 Periodic interactions of GH-releasing facto and somatostatin can augment GH release in vitro. Am J Physiol 253:E508-E514

38. Stachura ME, Tyler JM, Farmer PK 1988 Combined effect of human growth hormone (GH)-releasing factor-44 (GRF) and somatostatin (SRIF) in post-SRIF rebound release of $\mathrm{GH}$ and prolactin: a model for GRF-SRIF modulation of secretion. Endocrinology 123:1476-1482

39. Berelowitz M, Szabo M, Frohman LA, Firestone SL, Chu L 1981 Somatomedin-C mediates growth hormone negative feedback by effects on both the hypothalamus and the pituitary. Science 212:1279-1281

40. Powell D, Rosenfeld R, Baker B, Liu F, Hintz R 1986 Serum somatomedin levels in adults with chronic renal failure: the importance of measuring insulin-like growth factor 1 (IGF-1) and IGF 2 in acid-chromatographed uremic serum. J Clin Endocrinol Metab 63:1186-1192

41. Blum WF, Ranke MB, Kietzmann K, Tönshoff B, Mehls O 1991 Growth hormone resistance and inhibition of somatomedin activity by excess of insulin-like growth factor binding protein in uraemia. Pediatr Nephrol 5:539-545

42. Fagin JA, Fernandez-Mejia C, Melmed S 1989 Pituitary insulin-like growth factor-I gene expression: regulation by triiodothyronine and growth hormone. Endocrinology 125:2385-2391

43. Berelowitz M, Firestone SL, Frohman LA 1981 Effects of growth hormone exces and deficiency on hypothalamic somatostatin content and release and on tissue somatostatin distribution. Endocrinology 109:714-719

44. Blum WF 1991 Insulin-like growth factors (IGFs) and IGF binding proteins in chronic renal failure: evidence for reduced secretion of IGFs. Acta Paediatr Scand Suppl 379:24-31

45. Poletti LF, Krieg Jr RJ, Santos F, Niimi K, Hanna JD, Chan JCM 1992 Growth hormone secretory capacity of individual somatotropes in rats with chronic renal insufficiency. Pediatr Res 31:528-531

46. Metzger DL, Kerrigan JR, Krieg Jr RJ, Chan JCM, Rogol AD 1993 Alterations in the neuroendocrine control of growth hormone secretion in the rat. Kidney Int 43:10421048

47. Challa A, Krieg RI, Thabet MA, Veldhuis JD, Chan JCM 1993 Metabolic acidosis inhibits growth hormone secretion in the rat: mechanism of growth retardation. Am J Physiol 265:E547-E553

48. Hartman ML, Veldhuis JD, Johnson ML, Lee MM, Alberti KGMM, Samojlik E Thorner MO 1992 Augmented growth hormone (GH) secretory burst frequency and amplitude mediate enhanced $\mathrm{GH}$ secretion during a two day fast in normal men. $\mathrm{J}$ Clin Endocrinol Metab 74:757-765

49. Asplin CM, Faria ACS, Carlsen EC, Vaccaro VA, Barr RE, Iranmanesh A, Lee MM Veldhuis JD, Evans WS 1989 Alterations in the pulsatile mode of growth hormone release in men and women with insulin-dependent diabetes mellitus. J Clin Endocrinol Metab 69:239-245

50. Tannenbaum GS, Rorstad O, Brazeau P 1979 Effects of prolonged food deprivation on the ultradian growth hormone rhythm and immunoreactive somatostatin tissue levels in the rat. Endocrinology 104:1733-1738

51. Tannenbaum GS, Colle E, Gurd W, Wanamaker L 1981 Dynamic time-course studies of the spontaneously diabetic BB Wistar rat. I. Longitudinal profiles of plasma growth hormone, insulin, and glucose. Endocrinology 109:1872-1879

52. Clark RG, Jansson JO, Isaksson OGP, Robinson IAC 1985 Intravenous growth hormone: growth responses to patterned infusions in hypophysectomized rats. J Endocrinol 104:53-61

53. Isgaard J, Carlsson L, Isaksson OGP, Jansson JO 1988 Pulsatile intravenous growth hormone $(\mathrm{GH})$ infusion to hypophysectomized rats increases insulin-like growth factor I messenger RNA in skeletal tissues more effectively than continuous GH infusion. Endocrinology 123:2605-2610

54. Barash I, Madar Z, Gertler A 1983 Down-regulation of prolactin receptors in the liver, mammary gland and kidney of female virgin rat, infused with ovine prolactin or human growth hormone. Biochem Biophys Res Commun 116:644-650

55. Tönshoff B, Eden S, Weiser E, Carlsson B, Robinson IACF, Blum WF, Mehls O 1994 Reduced hepatic growth hormone $(\mathrm{GH})$ receptor gene expression and increased plasma GH binding protein in experimental uremia. Kidney Int 45:1085-1092

56. Kagan A, Zadik Z, Gertler A, Ulman M, Bar-Khayim Y 1993 Serum concentrations and peritoneal loss of growth hormone and growth-hormone-binding protein activity in older adults undergoing continuous ambulatory peritoneal dialysis: comparison with haemodialysis patients and normal subjects. Nephrol Dial Transplant 8:352-356 